\title{
A Study of College Students' Innovative Spirit and Practical Ability Cultivation
}

\author{
Xianfa Lan
}

NanChang Institute of Science \& Technology, Jiangxi Nanchang 330108

Keywords: Innovative spirit; Practical ability; College students; Talent quality

\begin{abstract}
With the high-speed development of the economic society and the more competitive job market, it is very urgent to cultivate high quality talents with innovation and entrepreneurship. To cultivate the college students' innovative spirit and entrepreneurial ability is of great significance to foster applied talents, relieve employment pressure, promote social and economic development, and realize individual value of college students. Under the influence of colleges and universities' expansion of student enrollment and the increase of employment pressure, the job market puts forward higher standards on talents. Cultivating the college students' innovative spirit and entrepreneurial ability has become a strategic task. To strengthen the cultivation of college students' innovative spirit and entrepreneurial ability comprehensively and effectively has become an important task being faced by China's higher learning reform and development. Through the cultivation, it can make more and more students keep up with the pace of the times, set up the new view of employment, put self-employment as priority to realize life value, and actively respond to the complex changes of the enterprises.
\end{abstract}

\section{Introduction}

The human talent resources have become the most strategic "first resources" in the 21 st century. The Party Central Committee stands at the height of modernization construction, establishes the reform and opening-up policy, and makes a major decision on the implementation of the strategy of Strengthening the Nation on Talent. The key of the strategy is the talent. Who has the high quality of innovative talents will be able to take the controlling position in the fierce international competition.

Colleges and universities as an important base for personnel training and the strategic highland for talent gathering, take on heavy responsibility to cultivate tens of millions of professional personnel and a large number of top-notch creative talents, construct an excellent teacher team, and build a high-level talent team. The universities students are the hope of the nationality and the future of the motherland. The implementation of the points raised from the 16th CPC National Congress' report, that whether the grand goal of building a well-off society in an all-round way can be realized smoothly, whether China can stand out in the current increasingly fierce international competition, and whether the goal of building a socialist harmonious society can be achieved, depends on the progress of science and technology, the cultivation of innovative ability, and the quality of the college students who are the social competition participants in the future. Therefore, we must stand at the front of the age to deeply recognize the special status and significance of cultivating college students' innovative spirit and ability, effectively play the function of science and technology education in colleges and universities, and strive to cultivate college students' innovative spirit and practical ability.

\section{The Importance of Cultivating College Students' Innovative Spirit and Entrepreneurship}

The Need to Cultivate Practice Oriented Talents. Throughout the educational philosophy of the domestic colleges and universities, the word "Innovation" appears in the school-running features, in the campus spirit, and also in the development strategy. For colleges and universities with the popularization of higher education in China, cultivating the application-oriented talent with innovation has become the lifeline of their survival and development. It requires colleges and 
universities to put the talent cultivation on an unprecedented height, establish a wide range of quality standards, innovate the personnel training mode, improve the talents quality, and meet the social demands maximumly. Seeking existence by quality and seeking development with its own feature are the way to maximumly cultivate the application-oriented talents who will serve for the social and local economic development.

Alleviate the Pressure of Employment. With the continuous expansion of colleges enrollment, the number of college graduates is increasing year by year, which means more and more college graduates will flood into the job market. It is difficult for the enterprises and public institutions to accommodate such number of graduates, which will undoubtedly bring heavy pressure on the society. Therefore, cultivating the innovative spirit and entrepreneurial ability of college students and leading more college students to join in the entrepreneurial group are the important channels to relieve the pressure of employment, enhance college students' competitiveness, and accept the social challenges.

Maintain the Steady Economic Growth. Entrepreneurship is an important engine and tool for economic growth. It makes a long-term and potential contribution to economic growth, the main performance of which are the economic aggregate increase, the economic efficiency improvement, and technological innovation. In the process of economic activities, entrepreneurship will inevitably cause the changes of industrial structure, improve the industry performance, and increase enterprises' competition in the market. So, in this way it can promote the social economic growth. The colleges and universities as a cradle of talent training, shouldering the important task to foster talents with innovative and entrepreneurial ability. The establishment of a university's innovation system will play an active role in supporting and promoting the establishment of the national innovation system, building an innovation-oriented country, and promoting national economic growth.

\section{The Cultivation of College Students' Innovative Spirit and Quality}

Innovation is the necessary of human development. The progress of human civilization is accompanied with the emergence of new thoughts, new ideas, new discoveries, new inventions, new creations, and new methods. Currently, the university education is mainly based on knowledge study and reasonable knowledge structure construction. In this process, in addition to inherit the knowledge created by predecessors and comprehend and the existing knowledge, college students also need to carry out innovative learning. What is the most important factor for innovative learning is to cultivate college students' innovative spirit and shape their innovative character through innovative education.

The college students should have courage to challenge the existing knowledge and ideas, abandon the outdated concepts, and create the new ones. In the daily school life, the college students should not stick in the mud, not follow suit blindly, but develop independent thinking ability with strong problematic awareness, proceed from the reality, and continue to discover new problems. The times proposes problems and the theory solves them. The bold innovation lays in the interaction between theory and practice, and promotes the development of the economy and society. The college teachers should train students with ability of judgement and critical spirit, encourage students to break through the old conventions and challenge the old academic system and knowledge system to invent the new way of knowledge creation.

\section{The Teaching Practice and Innovative Education Practice of the Universities}

Actively Promote Scientific Research Activities and Implant Scientific Concepts into Students' Minds. The establishment of the scientific research project system is helpful for the college students expand their horizons and set up the scientific views in the scientific research training activities. The college students can participate in the scientific research activities either through free combination, or guided by the teachers. The teachers should impart their rich research experience to the students by mentoring as well as fostering their individual study ability, 
highlighting part of the scientific research contents to allow students to explore independently, and develop students' ability to analyze and solve problems independently.

Create Scientific and Technological Innovation Campus Atmosphere. With the viewpoint of scientific development and building harmonious campus, the main route to promote the development of college students' quality and personality is the scientific activities. To make full use of the extracurricular teaching, to regularly held a variety of academic lectures, salons and report meetings, to publish science essays, and to encourage students to take part in academic activities dabbling in different disciplines are the good ways to strengthen students' innovation consciousness and develop their creative thinking. College students can explore related knowledge and technical abilities self-consciously in the various of scientific activities and develop themselves gradually. In this way, they can find the most appropriate areas to give full play to potential intelligence and make what they have learned available for earnings.

Cultivate Students' Practical Ability through Practical Training. Currently, more and more colleges and universities are aware of the importance of practical training to improve students' innovation ability. They increase investment in practical training's software and hardware construction, in order to provide students with optimal environment for their innovation ability development. Practical training reform should be carried out as follows. First, innovate the practice training content, reducing or canceling the simple repetition and confirmatory experiments, but adding some practical researchable study with designability and comprehensiveness. Second, establish the open experiment teaching model, of which students play as main body and teachers as leadership. The experiment contents, experiment facilities, and laboratory management should be available for the students, as it can promote their independent exploration ability. Third, improve the teaching tools by Integrating multimedia teaching, computer-assisted instruction, and other modern education technologies into practical teaching. Moreover, to make use of virtual and imitation technique for experiment operation can give much information to the class.

\section{Conclusion}

The cultivation of innovative talents should not be separated from social practice activities, which are important for college students to grasp employment and entrepreneurial opportunities. The innovation spirit and practical ability cultivation are the important part to promote overall quality education. The essay illustrates the significance to cultivate college students' innovation spirit from three aspects, of which they are helpful to relieve employment pressure, to increase economic development, and to keep social stability. Moreover, the essay analyzes the important methods to shape college students' innovative spirit and lists the examples that what kind of help that colleges and universities should provide for college students. In short, to cultivate college students' innovative spirit and entrepreneurial ability are of great significance to train applied talents, alleviate employment pressure, promote social and economic development, and achieve personal values. Colleges and universities should take a variety of effective measures to create cultural atmosphere of creativity and innovation, build innovative and entrepreneurial education platform for college students, and improve their innovational and entrepreneurial ability effectively.

\section{References}

[1] T.Z Wang, W.U Yan-Bo, Prospection of Ideological and Political Education for University Stu dents[J]. Journal of Hubei University, 2004.

[2] X.H Yang, On Integrating the Socialist Core Value System into the Whole Process of College Students' Ideological and Political Education[J]. Journal of Northeast Normal University, 2009.

[3] Chen J, nalyse the Undergraduates' Ideological and Political Education and Their Professional Training[J]. Guide of Science \& Education, 2011, 46(4):1421-1430. 
[4] J.M Li, Chen L, G.U Rong, On the Discussion of Specialty Teachers' Attendance in College Student Ideological and Political Education[J]. Journal of Lanzhou Petrochemical College of Vocational Technology, 2007.

[5] J Huang, J Lan, Ideological and Political Education:As Ideology State Apparatus— — Studies of a Meta-problem of Ideological and Political Education[J]. Journal of Wuhan University of Technology, 2009.

[6] Y Liu, The Features of College Students after "90S" and New Challenges to Internet-based Ideological and Political Education in Colleges[J]. Journal of Hebei Polytechnic University, 2010.

[7] Y Dai, Z Dong, On the Subject of Communication of Ideological and Political Education[J]. Teaching \& Research, 2014.

[8] Q Chu, XY Liao, On Characters' Function in Ideological and Political Education[J]. Journal of Yanan University, 2010.

[9] H Li, On the Philosophical Conception of the Value of Ideological And Political Education[J]. Teaching \& Research, 2014.

[10] Y Wang, LP Liu, Review on the Construction of the Subject of Ideological and Political Education in the Last Decade[J]. Teaching \& Research, 2014.

[11] Y.H Chen. The Application of Micro-blogging in Ideological and Political Education of College Students[J]. Journal of Wuhan Polytechnic, 2013.

[12] Wang L, Research In Ideological And Political Education[J]. Journal of Shandong Youth Administrative Cadres College, 2008. 